DOI https://doi.org/10.18551/rjoas.2018-10.15

\title{
FAMILY ABUSE: VICTIMS' SELF-RESISTANCE TO PHYSICAL VIOLENCE AND ROLE OF LAMONGAN RESORT POLICE (PPA UNIT)
}

\author{
Hidayati Fanani \\ Postgraduate School, University of Airlangga, Indonesia \\ E-mail: fananihidayati@gmail.com
}

\begin{abstract}
Resistance is directly carried out by victims by fighting directly against the perpetrators of violence, such as replying to acts committed by the perpetrator or reporting the perpetrators of violence to the authorities. Peaceful means carried out by the victims are without using a punitive path that focuses on repressive nature, namely by divorcing as a solution to the household problem. The way to divorce is considered effective because the victim no longer feels pain; the perpetrator is also not in prison. The role of the PPA Lamongan District Police Unit in resolving cases of domestic violence that occurred in Lamongan Regency is urgently needed, because the police are the spearhead when people need protection.
\end{abstract}

\section{KEY WORDS}

Family abuse, physical violence, Lamongan Regency, public relations.

Family abuse (known as KDRT in Indonesia) is the manifestation of gender inequity in the form of violence. The violence could be varies ranging from physical, mental, sexual and economic neglecting. Most of the physical abuse uses sharpened or solid stuff that would leave mark on its victim. Meanwhile, the mental health would be deceased by ruining the life of its victim. Another abuse, which is sexual, would not hesitate to commit raping. According to the data of women and child protection council, komnasperempuan.go.id, the number of KDRT, in personal affection of March $7^{\text {th }} 2016$, is $69 \%$ or 11.207 cases. The physical violence dominates the number by $38 \%$ or 4.304 . it is followed by sexual harassment by $30 \%$ or 3.325 cases, the mental abuse possesses $23 \%$ or 2.607 cases and the economic arousal has $9 \%$ or 971 cases. Moreover, the previous study conducted by Arfa states that the number of KDRT is increasing based on Jambi Police Office data of 2010-2013, the factors are varies from economic, Affair, and behaviour factor (Majalah hukum forum akademika vol,25).

Family abuse is a violation toward law and human right. In order to intercept and prevent the increasing number of family abuse, it is very important to increase the awareness of law toward women about their equity in family. If the victim is continuously received the physical abuse, they must report about the abuse quickly. Eventually, the attacker will have deterrent outcome not to repeat their commit.

\section{METHODS OF RESEARCH}

This study uses a qualitative method. Qualitative methods are used to get in-depth data, a data that contains meaning. (Sugiyono, 2015). Sources used are primary data sources which are data sources that directly provide data to data collectors, while secondary data sources are data sources that do not directly provide data to data collectors such as documents (Sugiyono, 2015). In this study, researchers used primary data sources. The criteria for primary data sources to be taken by researchers are informants who have been victims of physical violence in domestic violence. In addition, the researchers will collect data from the Lamongan District Police PPA unit which specifically handles domestic violence related problems. For data collection, qualitative research can be done in various ways, various sources and various settings. Data collection techniques can be done in four ways including observation (observation), interview (interview), questionnaire (questionnaire), documentation or a combination of the four (Sugiyono, 2015). 


\section{DISCUSSION OF RESULTS}

The self resistance performed by the victim in family abuse could be used to:

- Minimize and put an ends to the abuse. By performing the resistance, it will demonstrate that the women could stand against the domination of men in the family. The women will be notorious, thus the abuse will be intercepted or even to end it for once;

- Aware the attacker who are mainly men. In other way, by standing against the abuse, the victims would have a chance to prove to the world that after violations stomped to them, they still possessed courage. Eventually, the men will think twice before they commit another attack;

- Inspire other women. To inspire the women not to stay quiet and surrender when getting abused. Reporting the abuse to the officers, sometime, is seen as bad options as they have no gut to do so. But, they could use another way in order to intercept and minimize the abuse.

For the police department, one of preventive way to intercept the abuse is by holding socialisation. The head of PPA unit of Lamongan stated that their team commence an illumination whereas the participation are coming from sub-districts representation such as head sub-distrcit's wife, PKK, Muslimat, and Aisiyah. Technically, the awareness of family abuse among society must be increasing as the socialisation is already held across the region. Unfortunately, there is unmatched between the number of KDRT and case report from police. The PPA unit has no the data because of the small numbers of the report. Meanwhile, in this research, the study successfully gathered 13 informants from Paciran sub districts who are family abuse's victims. According to the Religion Court, the divorces that are caused by abuses exceed dozens each year. Here are the data of divorce that caused by physical abuse, in 2014 it states 2,03\%. In 2015, it increases 0.02 into 2,5\%. It is concluded that the divorce type is increasing from 2014 to 2015. It is recorded that there are 52 cases in 2014 and 67 cases in 2015 . The data is clashed with the one gathered by PPA unit as the number of reports to them is little. This unmatched data shows that the victims of family abuses prefer divorce to report the abuse. Therefore, the family abuse campaign must be spread more intense to society. That is why, the awareness will be increasing and the victim will not afraid to report the abuse to police as they already know the procedures from socialisation. The police also has system of procedures, as follow:

- Spreading the socialization throughout each sub-districts. The committee of socialization comes from PPA unit and local resort police officers. By doing illuminations, it is expected for the society to understand of what is family abuse, the law that regulates it, the procedures and etc. this sub-district level of socialization will require each representations of each village. Thus, the introduction of KDRT will be spread in entire breadth of region;

- PPA and KUA collaboration. The collaboration between PPA and KUA (Religion Courts Council) may inform people about the regulation of divorce or how to handle the abuse. Thus, the spouse will think twice before they commit any family abuse in their very own little family;

- Revitalizing the function of Bhabinkamtibnas in each village. The active function of Bhabinkamtibnas which is to prevent such cases and minimize the family abuse loop among society.

\section{CONCLUSION}

The resistances performed by the victims could be in a form of direct action by duplicating of what the attacker had done to them, and report the abuse to the officers. Another way to resist this phenomenon is by not using final attempts, which is one of repressive attempt; it is divorce way that is assumed as final option to put an end to the abuse. This repressive way is considered as the best way felt by the family as the victims will 
not receive any pain nor the attacker will serve in jail because of the action. The role of Lamongan PPA unit is very fundamental to overcome the family abuse cases as police is the front line when society merely needs such protection from their government. PPA unit still use mediation as their top priority to avoid divorce. But, if the mediation finds no good way, the unit will administrate their documents to the court. The problem arises when the spouse chose not to report their case to PPA that will result with small data that can be gathered by the unit. One of the factors is because the law awareness among society is still low. Most people still have an assumption that such reporting their inner problem to police is a disgrace. Even though, the number of divorce caused by physical abuse is dozens in each year. In contrast, the knowledge of society about their law consequences by performing divorce is very fundamental, the law is stated in article 14 act (c) law number 2 of 2002, it stated that the mandatory of police duty is commencing socialisation to increase people participation, the law awareness and the obedience of society to follow the rule. Thus, the number of family abuse will be easily intercepted. As one of preventive way, the PPA unit uses socialisation and become the informant on its event; the participants will come from each representation of sub-districts.

\section{SUGGESTIONS}

To maximise the awareness of family abuse, it is good option for PPA unit of Lamongan resort police to socialise to each sub districts. It is expected for each village would send their delegations to the socialisation. Surely, the unit must cooperate with local Bhabinkamtibnas as escort form each village. Moreover, the unit may cooperate with local religion court council to inform people about KDRT. Thus, the spouse that will do marriage already had an education about the dangerous will of family abuse. The spouse will think twice before they commit any kind of family abuse especially the physical abuse that may threaten the live of its victim. The sector police of each sub district may mandate their Bhabinkamtibnas personnel to spread the awareness as well. The challenge occurs to Bhabinkamtibnas, them must able to pursue and convince people that police officers will protect and guide them. Eventually, the society will not see reporting the abuse as disgrace to family but law procedures instead.

\section{REFERENCES}

1. Afandi, D., Rosa, W.Y., Suyanto., Khodijah., dan Widyaningsih, C. 2012. Karakteristik Kasus Kekerasan dalam Rumah Tangga. J Indon Med Assoc,. Vol.62, no.11.

2. Arfa, N. 2014. Penanggulangan Kekerasan Dalam Rumah Tangga Di Kota Jambi. Majalah Hukum Forum Akademika. Vol.25, no.1.

3. Asmarany, A.I. Bias Gender sebagai Prediktor Kekerasan Dalam Rumah Tangga. Jurnal Psikologi. Vol.35, no.1, 1-20.

4. Narwoko, J.D., \& Suyanto, B. 2011. Sosiologi: Teks Pengantar dan Terapan. Kencana Prenada Media Group. Jakarta.

5. Sugiyono. 2015. Metode Penelitian \& Pengembangan: Research and Development. Alfabeta. Bandung.

6. Sunarso, S. 2015. Pengantar Ilmu Kepolisian. Pustaka Perdamaian Nusantara. Jakarta.

7. Suparlan, S. 2011. Bunga Rampai IImu Kepolisian Indonesian. YPKIK (Yayasan Pengembangan Kajian Ilmu Kepolisian. Jakarta.

8. Wijaya, H.Y. 2016. Mengusung Pengantar Kajian Queer didalam Ruang Kuliah: Sebuah Refleksi (Introducing Queer Studies in the Classroom: A Reflection. Jurnal Perempuan, UDC 305, 24-42. 